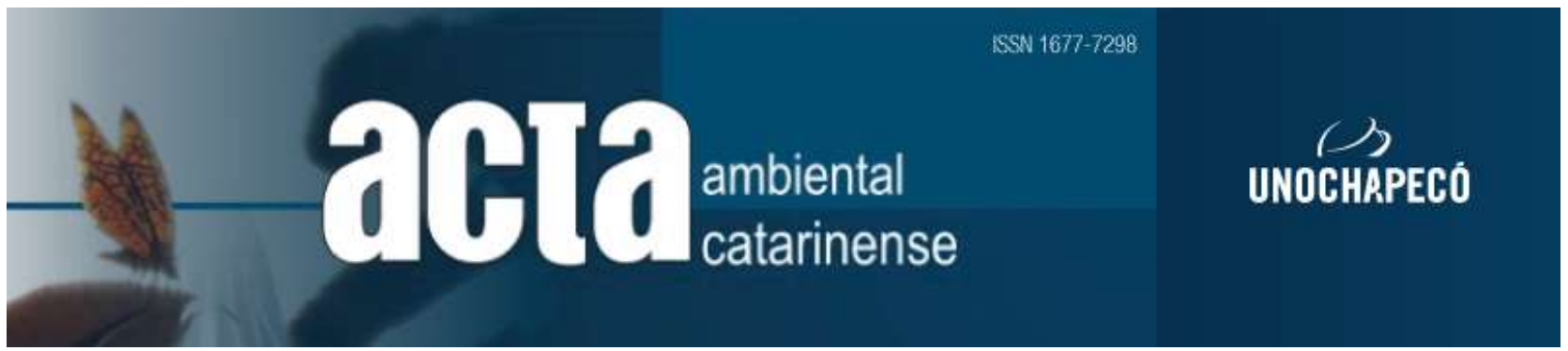

\title{
SOIL REHABILITATION AND GROWTH OF PINUS TAEDA AND EUCALYPTUS SALIGNA IN A DEGRADED AREA BY COAL MINING
}

\section{REABILITAÇÃO DE SOLO E CRESCIMENTO DE PINUS TAEDA E EUCALYPTUS SALIGNA EM UMA ÁREA DEGRADADA PELA MINERAÇÃO DE CARVÃO}

\author{
Patricia Pértile ${ }^{1 *}$ \\ Jackson Adriano Albuquerque ${ }^{1}$ \\ Luciano Colpo Gatiboni $^{2}$ \\ Rodrigo Vieira Luciano ${ }^{3}$ \\ Bruno Batistella $1^{1}$
}

\begin{abstract}
Resumo
Para a reabilitação de solos degradados por mineração de carvão a céu aberto é necessário corrigir a acidez e os teores de nutrientes e promover a revegetação. Foram avaliados os efeitos de diferentes métodos de reabilitação de uma área degradada pela mineração de carvão sobre os atributos químicos e físicos do solo construído e sobre o crescimento de pinus e eucalipto. O experimento foi estabelecido entre 2001 e 2004 no sul do Brasil, utilizando tratamentos com calcário, capimbraquiária (Urochloa brizantha) e cama de aviário. Mudas de Pinus taeda e Eucalyptus saligna foram plantadas em 2004. Em 2010, amostras de solo foram coletadas nas camadas de 0-5 e 5-10 cm para análises químicas e físicas, e a altura e diâmetro das árvores foram medidas. A cama de aviário e o capim-braquiária não afetaram os atributos químicos do solo, mas o capim-braquiária reduziu a resistência do solo à penetração. $\mathrm{O}$ calcário aumentou o $\mathrm{pH}$ do solo, os teores de cálcio e magnésio e a saturação por bases e diminuiu a saturação de alumínio, porém, a dificuldade de incorporação do calcário resultou na supercalagem da camada superficial do solo, o que diminuiu o crescimento do pinus. O crescimento de eucalipto diminuiu com capim-braquiária e cama de aviário, mas teve crescimento deficiente em toda a área devido, provavelmente, às limitações físicas (baixa porosidade) e químicas (baixo teor de fósforo). Portanto, em solos construídos similares, o
\end{abstract}

\footnotetext{
${ }^{1}$ Department of Soils and Natural Resources, Santa Catarina State University (UDESC), Lages, SC, 88520-000, Brazil.

${ }^{2}$ Soils Department of Crop and Soil Sciences, North Carolina State University, Raleigh NC, 27695, U.S.A.

${ }^{3}$ Federal Institute of Education, Science and Technology of Rio Grande do Sul (IFRS), Bento Gonçalves, RS, 95700-206, Brazil.

*Corresponding author: patricia_pertile@ @otmail.com
} 
reflorestamento com Eucalyptus saligna pode não ser indicado, enquanto o reflorestamento com Pinus taeda é viável com menores doses de calcário.

Palavras-chave: calcário, cama de aviário, Urochloa brizantha, espécies florestais exóticas.

\begin{abstract}
For rehabilitation of degraded soil by open-pit coal mining it is necessary to correct the acidity and nutrients contents and promote revegetation. We evaluated different rehabilitation methods of a degraded area by coal mining on constructed soil chemical and physical attributes, and on growth of pine and eucalypt. The experiment was established between 2001 and 2004 in southern Brazil using treatments with lime, palisade grass (Urochloa brizantha), and poultry litter. Seedlings of Pinus taeda and Eucalyptus saligna were planted in 2004. In 2010, soil samples were collected at 0-5 and 5-10 cm layers for chemical and physical analysis and height and diameter of the trees were measured. Poultry litter and palisade grass did not affect soil chemical attributes, but palisade grass reduced soil penetration resistance. Lime increased soil $\mathrm{pH}$, calcium and magnesium contents and base saturation and decreased aluminum saturation, however, the difficulty of lime incorporation resulted in overliming in the soil surface layer, however, the difficulty of lime incorporation resulted in overliming in the soil surface layer, which decreased pine growth. The growth of eucalypt decreased with palisade grass and poultry litter but had impaired growth throughout the area due probably to the physical (low porosity) and chemical (low phosphorus) limitations. Therefore, in similar constructed soils the reforestation with Eucalyptus saligna cannot be indicated, while reforestation with Pinus taeda is viable with lower rates of lime.
\end{abstract}

Keywords - lime, poultry litter, Urochloa brizantha, exotic forest species.

\section{INTRODUCTION}

Coal reserves in Brazil total more than 32 billion tons, almost all of them in southern Brazil (EPE, 2017). However, the coal extraction is potentially polluting due to the production and accumulation of large volumes of waste, change in landscape, and contamination of soil and water resources (GUEBERT and GARDNER, 2001; GAIVIZZO et al., 2002; COSTA and ZOCCHE, 2009; CAMPOS et al., 2010; STUMPF et al., 2014; PARK et al., 2014).

Coal mining in Brazil is carried out in underground or open-pit mines. In the openpit exploration, the soil and layers of rocks are removed to allow extraction of the coal. Subsequently, the rehabilitation of these areas should be performed with soil topographic reconstruction and reshaping the landscape
(GAIVIZZO et al., 2002; COSTA and ZOCCHE, 2009). However, this rehabilitation usually results in soils with physical restrictions, such as low porosity and water infiltration, and high stoniness and water erosion (GUEBERT and GARDNER, 2001; CAMPOS et al., 2010; STUMPF et al., 2014, 2016a); and in soil contamination by coal residues and acid drainage originated from sulfides, mainly pyrite $\left(\mathrm{FeS}_{2}\right)$ (CAMPOS et al., 2003, 2010; BITENCOURT et al., 2015). The oxidation of pyrite acidifies the soil, accelerates the weathering of minerals, raises aluminum and manganese contents and increases base leaching (CAMPOS et al., 2003; BITENCOURT et al., 2015), besides reducing the amount and diversity of microorganisms, and soil biological activity (QUADROS et al., 2016; STUMPF et al., 2018b). 
In order to favor the rehabilitation of those areas, the soil must be revegetated to increase the organic matter content and biological activity and reduce water erosion (GAIVIZZO et al., 2002; GONZÁLEZALDAY et al., 2009; REIS et al., 2014). However, it is difficult for plants to explore deeper layers due to the chemical and physical restrictions of these reconstructed soils (GUEBERT and GARDNER, 2001; CAMPOS et al., 2010), which makes necessary the addition of acidity correctives, fertilization (BENDFELDT et al., 2001; PARK et al., 2011, 2014), and cultivation of cover crops (GONZÁLEZ-ALDAY et al., 2009; REIS et al., 2014), among other practices. Thus, organic fertilization, roots of plants, and organic carbon from vegetation cycling stimulates the growth of microorganisms (WANG et al., 2015; STUMPF et al., 2018b) and soil restructuring (LUNARDI NETO et al., 2008; STUMPF et al., 2014, 2016a; WANG et al., 2017).

In the recovery or restoration of degraded areas for environmental conservation purposes, the use of native forest species is recommended (SANTA CATARINA, 2012). In the case of degraded areas intended for commercial use, fastgrowing exotic forest species of economic importance such as pine and eucalypt can be grown (SANTA CATARINA, 2009). However, to allow the planting of native or exotic vegetation, adequate soil physical and chemical conditions must be provided.

Among the studies demonstrating the effects of soil fertility and revegetation on the quality of soils reconstructed after coal mining, Lunardi Neto (2006) observed that lime application increased the $\mathrm{pH}$ and the availability of basic cations but organic fertilization and palisade grass as cover crop had a lesser impact on soil physical parameters after six months. It is expected that, after a longer time, the liming complemented with organic fertilization and green covering, increase the soil organic matter and the supply of nutrients. This can also lead to an increase in the soil physical quality, especially in terms of density and porosities, allowing adequate growth of species for commercial purposes.

The objective of this study was to evaluate the chemical and physical attributes of a constructed soil in a topographically reconstructed area after coal mining and the growth of Pinus taeda L. and Eucalyptus saligna $\mathrm{Sm}$. after six years of liming, organic fertilization with poultry litter, and covering with Urochloa brizantha.

\section{MATERIAL AND METHODS}

\subsection{Description of experiment and site}

The study was carried out in Lauro Müller, Santa Catarina (SC), Brazil (28 20' S and $49^{\circ} 20^{\prime} \mathrm{W}$ ) in an area with mining activity closed in 1992. It was topographically reconstructed in 1996, by filling the pit with mining tailings, rocks and soil (CAMPOS et al., 2003). A soil layer of approximately $30 \mathrm{~cm}$ was added over those materials, coming from the horizons $\mathrm{A}$ and $\mathrm{B}$ of an Ultisol according to Soil Taxonomy (USDA, 2010) (Argissolo Vermelho-Amarelo Alumínico típico in the Brazilian Soil Classification System (SANTOS et al., 2018)), located in a neighboring area. The soil texture was loam (360, 373 and $267 \mathrm{~g} \mathrm{~kg}^{-1}$ of sand, silt and clay, respectively) and cation exchange capacity (CEC) at $\mathrm{pH} 7.0$ (determined according to Claessen et al. (1997)) was 19.0 cmol $_{\mathrm{c}} \mathrm{kg}^{-1}$ from 0 to $10 \mathrm{~cm}$ soil depth.

In 2001, the constructed soil was showing intense degradation, water erosion and incipient vegetal cover (LUNARDI NETO, 2006). In November 2001, the entire site was submitted to subsoiling and stones were removed from the surface. Due to the high acidity and low nutrient availability, 66 $\mathrm{kg} \mathrm{ha}^{-1}$ of $\mathrm{N}$ (urea), $110 \mathrm{~kg} \mathrm{ha}^{-1}$ of $\mathrm{P}_{2} \mathrm{O}_{5}$ (triple superphosphate) and $110 \mathrm{~kg} \mathrm{ha}^{-1}$ of $\mathrm{K}_{2} \mathrm{O}$ (potassium chloride) were applied on the soil 
surface, as recommended for warm season grasses (CFS-RS/SC, 1994).

The experimental design was randomized blocks with four treatments and three replicates, totaling 12 plots of $12.5 \mathrm{~m} \mathrm{x}$ $9.0 \mathrm{~m}$ each. The treatments were applied in November 2001 and reapplied in August 2004, as follows: (i) control; (ii) lime; (iii) lime + palisade grass $(\mathrm{L}+\mathrm{G})$; and (iv) lime + palisade grass + poultry litter $(\mathrm{L}+\mathrm{G}+\mathrm{PL})$. The reapplication of treatments was necessary because eucalypt seedlings planted in November 2001 did not develop properly and were uprooted in 2004, as described by Lunardi Neto et al. (2008).

In each treatment, the following interventions were performed: (i) control - did not receive lime (only received lime in the planting pit), nor palisade grass, nor poultry litter; (ii) lime - received $25 \mathrm{Mg} \mathrm{ha}^{-1}$ of dolomitic lime (total neutralizing power, TNP, of $100 \%$ ) in 2001 and $13 \mathrm{Mg} \mathrm{ha}^{-1}$ in 2004; (iii) lime + palisade grass $(\mathrm{L}+\mathrm{G})-$ received the same management of the treatment lime and sowing (without incorporation) of $6 \mathrm{~kg} \mathrm{ha}^{-1}$ of palisade grass (Urochloa brizantha) in 2001 and $6 \mathrm{~kg} \mathrm{ha}^{-1}$ in 2004; (iv) lime + palisade grass + poultry litter $(\mathrm{L}+\mathrm{G}+\mathrm{PL})-$ received the same management of the treatment $\mathrm{L}+\mathrm{G}$ and application of poultry litter at doses (dry basis) of $6 \mathrm{Mg} \mathrm{ha}^{-1}$ in 2001 (CFS-RS/SC, 1994) and $9 \mathrm{Mg} \mathrm{ha}^{-1}$ in 2004 (CQFS-RS/SC, 2004), following Local Soil Fertility Committee. Lime rates were determined by the SMP index to raise soil $\mathrm{pH}$ to 6.0 in the $0-20 \mathrm{~cm}$ soil layer in 2001 (CFS-RS/SC, 1994) and in 2004 (CQFS-RS/SC, 2004)

Lime and poultry litter were applied and incorporated in August 2004 with subsoiling and harrowing, using a subsoiler with 5 shanks spaced by $40 \mathrm{~cm}$ that operated at a depth of $25 \mathrm{~cm}$, and a disc harrow with 12 discs of $30 \mathrm{~cm}$ in diameter that operated at a depth of 10 to $15 \mathrm{~cm}$. However, due to the presence of rocks, the incorporation was not carried out properly (LUNARDI NETO et al., 2008). Those operations were also performed in the control treatment to avoid differences in soil structure between treatments. Afterwards, we also applied $66 \mathrm{~kg} \mathrm{ha}^{-1}$ of $\mathrm{N}$ (urea), $110 \mathrm{~kg}$ $\mathrm{ha}^{-1}$ of $\mathrm{P}_{2} \mathrm{O}_{5}$ (triple superphosphate) and 110 $\mathrm{kg} \mathrm{ha}^{-1}$ of $\mathrm{K}_{2} \mathrm{O}$ (potassium chloride).

In the control and lime treatments (the two treatments without palisade grass) the soil remained uncovered until the growth of spontaneous plants; and in the $\mathrm{L}+\mathrm{G}$ and $\mathrm{L}+\mathrm{G}+\mathrm{PL}$ treatments the soil remained covered with palisade grass, as part of the treatment itself. In October 2004, 15 seedlings of Pinus taeda L. were planted on one side and 15 seedlings of Eucalyptus saligna $\mathrm{Sm}$. on the other side of each plot, with spacing of $1.5 \mathrm{~m}$ $\mathrm{x} 2.5 \mathrm{~m}$ for both species. This way, 30 planting pits $(0.2 \mathrm{~m} \times 0.2 \mathrm{~m} \times 0.2 \mathrm{~m})$ were digged in each plot. At this time, all planting pits of all treatments (including the control treatment) received $20 \mathrm{~g}$ of $\mathrm{N}$ (urea), $44 \mathrm{~g}$ of $\mathrm{P}_{2} \mathrm{O}_{5}$ (triple superphosphate), $44 \mathrm{~g}$ of $\mathrm{K}_{2} \mathrm{O}$ (potassium chloride), and $72 \mathrm{~g}$ of dolomitic lime (equivalent to $18 \mathrm{Mg} \mathrm{ha}^{-1}$ of lime with TNP of $100 \%)$. The fertilizers and the lime were homogenized with the soil of the pits. The lime was added in all pits to neutralize the acidity up to $20 \mathrm{~cm}$ depth (depth below the mobilized layer).

In December 2004, during the initial growth of the trees, the weeding was carried out around the seedlings, the aerial part of palisade grass was cut, and $40 \mathrm{~kg} \mathrm{ha}^{-1}$ of $\mathrm{N}$ (urea) were applied in all treatments (without incorporation). After this period, the experimental area was mowed annually, maintaining plant residues on the soil.

\subsection{Soil chemical and physical analysis}

In October 2010, soil penetration resistance (PR) was determined at five sites per plot with a digital penetrometer (Falker 1.11, Brazil), which operated with a cone tip rod of $12.8 \mathrm{~mm}$ in diameter and a penetration angle of $30^{\circ}$, a rate of maximum manual measurement of $50 \mathrm{~mm} \mathrm{~s}^{-1}$ and storage of data at each $1.0 \mathrm{~cm}$, grouped in the layers of $0-5$ and $5-10 \mathrm{~cm}$ with an average value of PR. On 
the same date, soil samples with altered and preserved structure (collected vertically with metal rings of $4.9 \mathrm{~cm}$ in diameter and $5.3 \mathrm{~cm}$ in height) were collected in the $0-5 \mathrm{~cm}$ and 5 $10 \mathrm{~cm}$ layers between the planting rows of the trees and in duplicate (two replicates), to analyze soil chemical and physical attributes. The presence of a strongly compacted subsurface layer in most of the experimental area did not allow soil samples to be collected below $10 \mathrm{~cm}$ depth.

The soil samples with preserved structure were saturated by capillarity, submitted to the water potential of $-6 \mathrm{kPa}$ in a sand suction column (REINERT and REICHERT, 2006) and oven-dried at $105^{\circ} \mathrm{C}$ for $48 \mathrm{~h}$, to determine the total porosity (TP, ratio between the volume of water retained in the saturated soil and soil volume), microporosity (Micro, ratio between the volume of water retained in the soil at water potential of $-6 \mathrm{kPa}$ and soil volume), and macroporosity (Macro, difference between TP and Micro) (CLAESSEN et al., 1997) and bulk density (BD, ratio between dry soil mass and soil volume) (BLAKE and HARTGE, 1986).

The soil samples with altered structure were oven-dried at $60{ }^{\circ} \mathrm{C}$, ground and sieved with a $2.0-\mathrm{mm}$ mesh for determination of $\mathrm{pH}$ in water, and contents of $\mathrm{K}^{+}, \mathrm{Na}^{+}, \mathrm{Ca}^{2+}, \mathrm{Mg}^{2+}$, $\mathrm{Al}^{3+}, \mathrm{P}$, and total organic carbon (TOC). The $\mathrm{pH}$ in water was determined at a 1:1 ratio (soil:distilled water) using a potentiometric $\mathrm{pH}$ meter. $\mathrm{Na}^{+}, \mathrm{K}^{+}$, and $\mathrm{P}$ were extracted by the double-acid extraction method (Mehlich1) with acid solution of $0.05 \mathrm{~mol} \mathrm{~L}^{-1} \mathrm{HCl}$ and $0.0125 \mathrm{~mol} \mathrm{~L}^{-1} \mathrm{H}_{2} \mathrm{SO}_{4} \cdot \mathrm{Na}^{+}$and $\mathrm{K}^{+}$were quantified by flame photometry, and $\mathrm{P}$ with absorbance reading in a UV-VIS spectrophotometer. $\mathrm{Ca}^{2+}, \mathrm{Mg}^{2+}$ and $\mathrm{Al}^{3+}$ were extracted with a neutral saline solution (1.0 mol L $\left.{ }^{-1} \mathrm{KCl}\right) . \mathrm{Ca}^{2+}$ and $\mathrm{Mg}^{2+}$ were determined by atomic absorption spectrophotometry, and $\mathrm{Al}^{3+}$ by acid-base titration with $0.0125 \mathrm{~mol} \mathrm{~L}^{-}$ ${ }^{1} \mathrm{NaOH}$ (TEDESCO et al., 1995). The TOC was determined by the Walkley-Black method modified by Tedesco et al. (1995), by oxidation with $1.25 \mathrm{~mol} \mathrm{~L}^{-1} \mathrm{~K}_{2} \mathrm{Cr}_{2} \mathrm{O}_{7}$ in a concentrated $\mathrm{H}_{2} \mathrm{SO}_{4}$ acid medium, and titration with $0.25 \mathrm{~mol} \mathrm{~L}^{-1} \mathrm{FeSO}_{4}$ (TEDESCO et al., 1995). The following attributes were calculated: $\mathrm{Ca} / \mathrm{Mg}$ ratio, effective cation exchange capacity $\left(\mathrm{CEC}_{\mathrm{ef}}\right)$, base saturation $(\mathrm{V}), \mathrm{Al}^{3+}$ saturation $(\mathrm{m})$ and $\mathrm{Na}^{+}$saturation (Sat ${ }_{\mathrm{Na}}$ ) according to Claessen et al. (1997).

\subsection{Tree analysis}

In October 2010, the diameter at 1.30 $m$ height, or diameter at breast height (DBH), and the total height of ten pine trees and ten eucalypt trees (with age of six years) per plot were measured using a tree caliper, an aluminum ruler of $6.0 \mathrm{~m}$ and a measuring tape of $15,0 \mathrm{~m}$. The ten trees of each species measured per plot were randomly selected from the 15 seedlings planted. With the ruler and the measuring tape, it was possible to measure trees up to approximately $9.0 \mathrm{~m}$ in height (with an aid of a rigid box for the operator elevation of approximately $0.5 \mathrm{~m}$ ). Thus, when necessary (height greater than 6.0 $\mathrm{m})$ one operator elevated the ruler until reach the top of the tree and another operator complemented the measurement to the base of the tree with a tape measure. Only in one plot the pine trees had height higher than $9.0 \mathrm{~m}$ (only ten trees out of a total of 300 trees measured), in which an estimate of the height was performed using the ruler and comparing with nearby trees of known height.

\subsection{Data analysis}

The data were submitted to ShapiroWilk normality test $(\mathrm{p}<0.05)$, to Bartlett homogeneity test $(\mathrm{p}<0.05)$, and to analysis of variance (ANOVA) by $\mathrm{F}$ test $(\mathrm{p}<0.05)$. The variables that did not have normal distribution or homogeneity of variance were submitted to Box-Cox transformation with Action software (EQUIPE ESTATCAMP, 2014). One-way ANOVA (four treatments) by soil layer sampled (0-5 and 5-10 cm) was performed for each soil variable; and one-way ANOVA 
(four treatments) by forest species (pine and eucalypt) was performed for each plant growth variable, both followed by Tukey test ( $\mathrm{p}<0.05)$ using the PROC GLM model. Pearson's linear correlation test was used to verify relationships between soil attributes and growth variables of pine and eucalypt. Statistical analysis were performed using the program SAS (SAS INSTITUTE, 2017).

\section{RESULTS AND DISCUSSION}

\subsection{Soil chemical attributes}

The treatments with lime increased soil $\mathrm{pH}$ (in water) to more than 7.0 in the $0-5$ $\mathrm{cm}$ layer, differing from the control $(\mathrm{pH} 4.1)$; and there was no influence of palisade grass and poultry litter (Figure 1A). In the $5-10 \mathrm{~cm}$ layer, the treatments lime and lime + palisade grass $(\mathrm{L}+\mathrm{G})$ raised the $\mathrm{pH}$ to an average of 6.1, but only the treatment lime + palisade grass + poultry litter ( $\mathrm{L}+\mathrm{G}+\mathrm{PL})(\mathrm{pH}$ 6.8) differed from the control ( $\mathrm{pH} 4.1)$. The increase of $\mathrm{pH}$ by the application and reapplication of lime at doses recommended by SMP $\mathrm{pH}$ decreased acidity in the soil surface layer, but raised soil $\mathrm{pH}$ excessively in the $0-5 \mathrm{~cm}$ layer, which is undesirable because it decreases the availability of micronutrients such as $\mathrm{Fe}, \mathrm{Zn}$, $\mathrm{Cu}$ and $\mathrm{Mn}$ by precipitation (HAYNES, 2009). Furthermore, although occurs a decrease in $\mathrm{P}$ adsorption at high $\mathrm{pH}$ values due to the higher number of negative charges in the soil, Ca phosphates are formed due to the high contents of $\mathrm{Ca}^{2+}$ (for example, due to overliming), which reduces $\mathrm{P}$ availability for plants (NOVAIS et al., 2007; HAYNES, 2009). The $\mathrm{pH}$ was evaluated only up to $10 \mathrm{~cm}$ deep and between the planting rows of the forest species; therefore, higher $\mathrm{pH}$ should occur near the roots due to the application of lime also in the soil volume of the planting pit. Consequently, more deficiency of micronutrients and $\mathrm{P}$ must have occurred at the beginning of the growth of pine and eucalypt seedlings, when their roots were more concentrated in the pits.

In soils with low $\mathrm{pH}$, as observed in the control, there is also low availability of $\mathrm{P}$ due to greater adsorption to the positive charges of $\mathrm{Fe}$ and $\mathrm{Al}$ oxides and the precipitation as $\mathrm{Fe}$ or $\mathrm{Al}$ phosphates of low solubility (NOVAIS et al., 2007). The maximum availability of $\mathrm{P}$ for plants in tropical soils - mainly composed of kaolinite and $\mathrm{Fe}$ oxides, similar to the soil of this study - occurs in a range of $\mathrm{pH}$ between 5.5 and 6.5 (MELLO and PEREZ, 2009). In treatments with lime (lime, $\mathrm{L}+\mathrm{G}$, and $\mathrm{L}+\mathrm{G}+\mathrm{PL}$ ), the $\mathrm{pH}$ was above this range in the $0-5 \mathrm{~cm}$ layer.

The recommendation of high doses of lime may have been caused by the analytical procedure in determining the need for lime, since the SMP solution used to determine the potential acidity is a basic solution with a high degree of buffering, which may have forced dissolution of pyrite particles present in the soil samples. On the other hand, in the experimental area, part of the pyrite could be more stabilized in the soil and, consequently, would not affect soil acidification so much. Therefore, the recommended doses of lime based on the SMP $\mathrm{pH}$ and the difficulty in lime incorporating due to the presence of rocks caused acidity correction above of desired levels. 


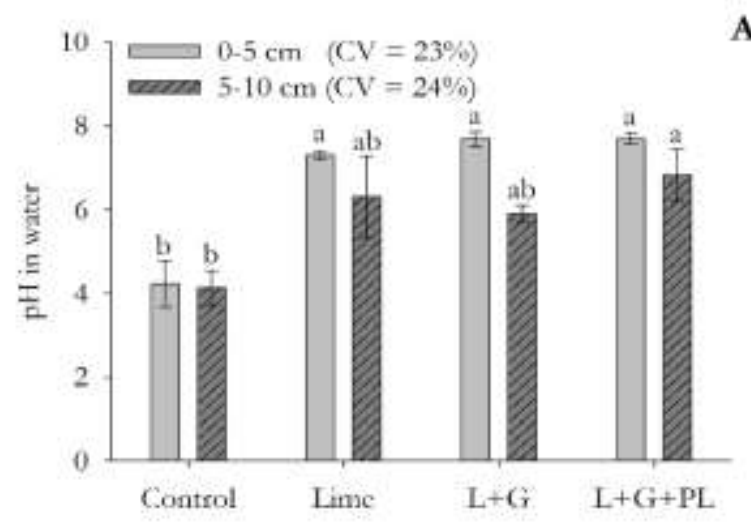

A
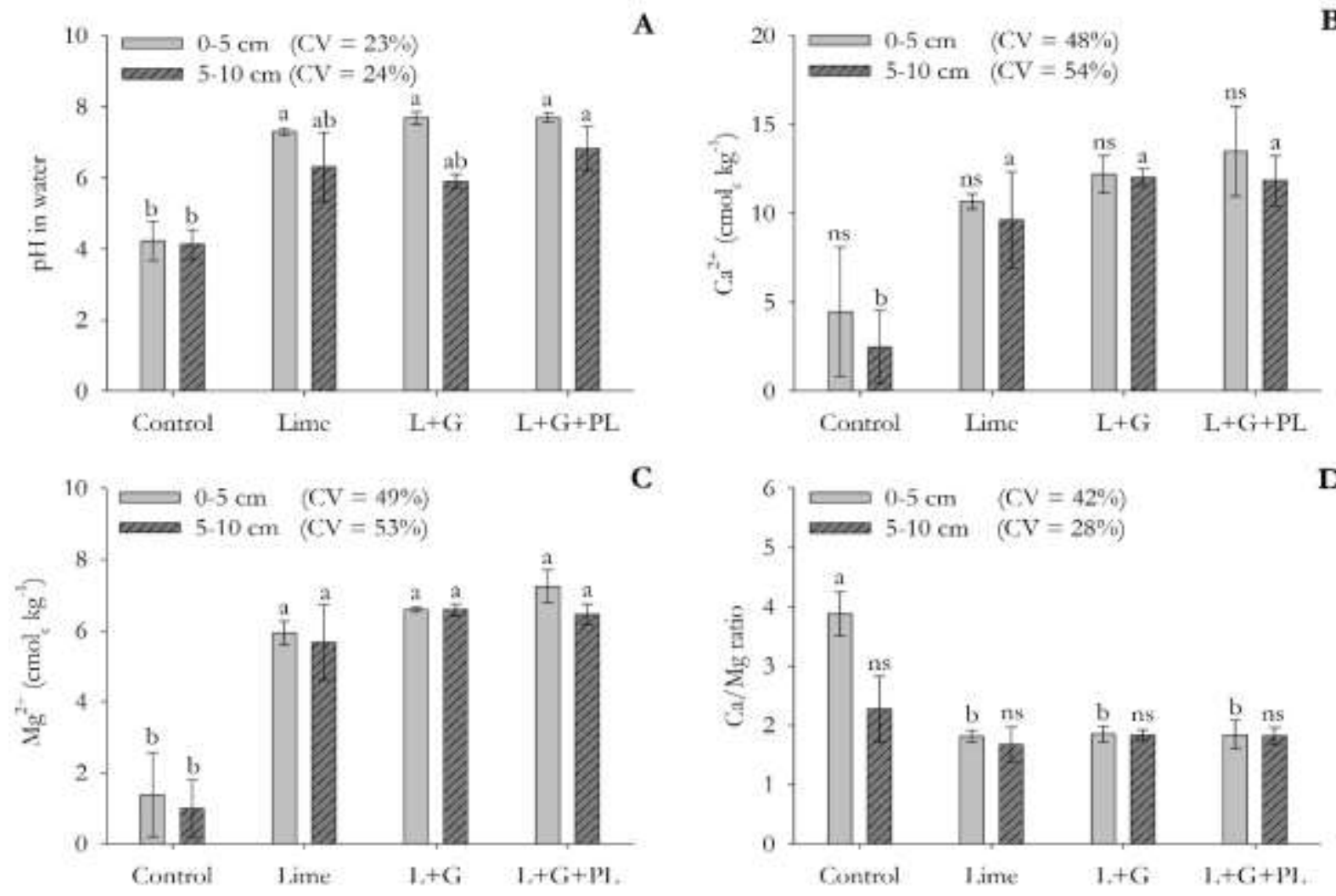

C
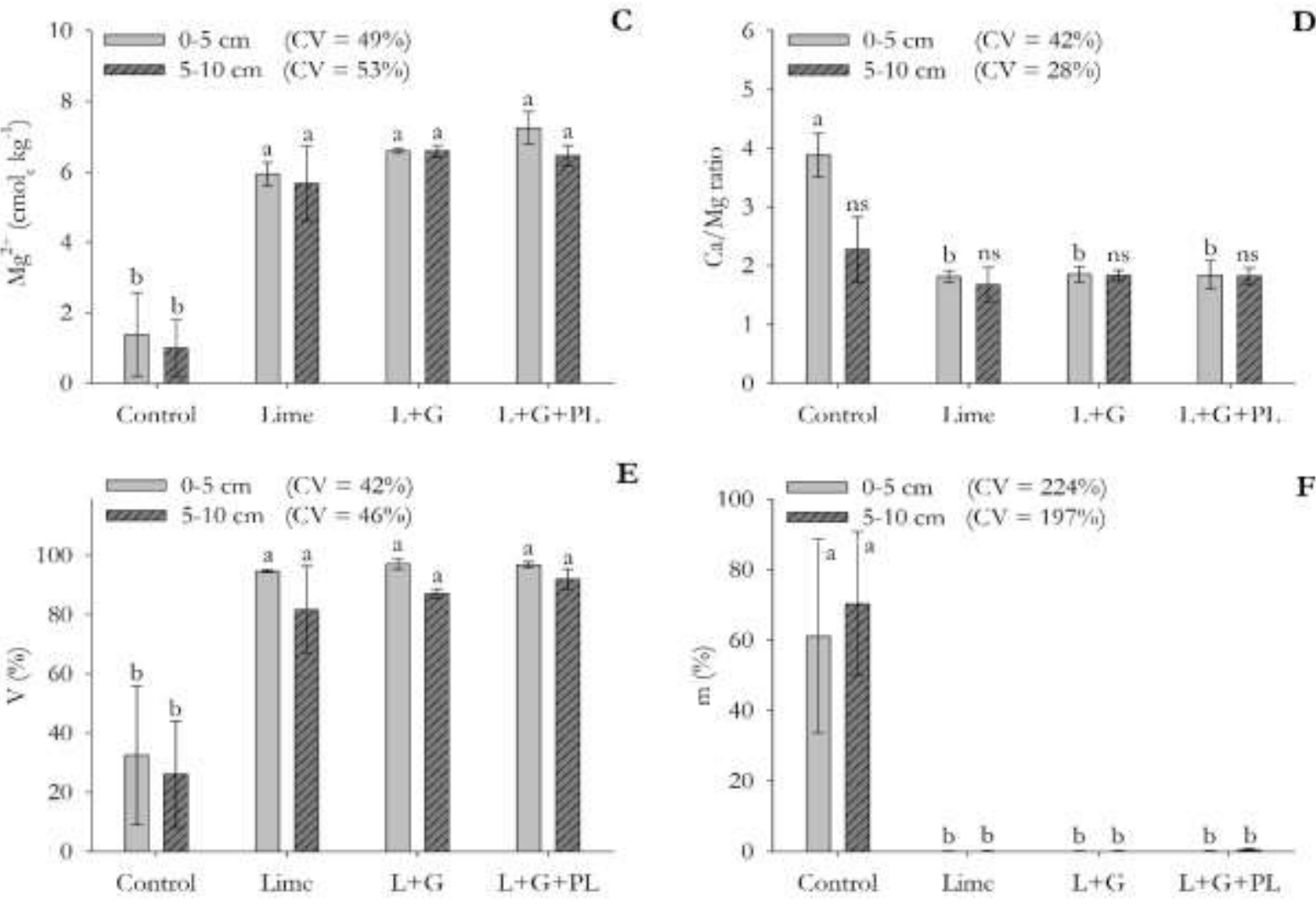

Figure 1. $\mathrm{pH}$ in water (A), $\mathrm{Ca}^{2+}(\mathrm{B})$ and $\mathrm{Mg}^{2+}$ contents $(\mathrm{C}), \mathrm{Ca} / \mathrm{Mg}$ ratio $(\mathrm{D})$, base saturation $-\mathrm{V}(\mathrm{E})$, and aluminum saturation $-\mathrm{m}(\mathrm{F})$ by constructed soil layer $(0-5$ and $5-10 \mathrm{~cm})$. For each layer, bars with different letters differ from each other and bars with ns (not significant) do not differ by Tukey test ( $\mathrm{p}$ $<0.05)$ and error bars denote standard error. Legend: $\mathrm{L}+\mathrm{G}$ - lime + palisade grass; $\mathrm{L}+\mathrm{G}+\mathrm{PL}-$ lime + palisade grass + poultry litter; $\mathrm{CV}-$ coefficient of variation. 
from $1.2 \mathrm{cmol}_{\mathrm{c}} \mathrm{kg}^{-1}$ in the control to $6.4 \mathrm{cmol}_{\mathrm{c}}$ $\mathrm{kg}^{-1}$ in the average of treatments (lime, $\mathrm{L}+\mathrm{G}$ and $\mathrm{L}+\mathrm{G}+\mathrm{PL}$ ) and soil layers (Figure $1 \mathrm{C}$ ). The critical levels of $\mathrm{Ca}^{2+}$ and $\mathrm{Mg}^{2+}$ in the soil for the growth of eucalypt with an average wood annual increment of $50 \mathrm{~m}^{3} \mathrm{ha}^{-1}$ year $^{-1}$ in Brazil are 0.80 and $0.19 \mathrm{cmol}_{\mathrm{c}} \mathrm{kg}^{-1}$, respectively (BARROS and NOVAIS, 1999). For Pinus taeda there are no specific calibrations of the need for $\mathrm{Ca}^{2+}$ and $\mathrm{Mg}^{2+}$ in the soil. Therefore, the levels of these basic cations in all treatments, including control, are at high levels for eucalypt growth and probably high for pine growth due to its lower fertility requirement when compared to eucalypt (PAIVA et al., 2011).

The $\mathrm{Ca} / \mathrm{Mg}$ ratio decreased from 4.0 in the control to approximately 2.0 in treatments with lime in the $0-5 \mathrm{~cm}$ layer but did not differ between treatments in the $5-10 \mathrm{~cm}$ layer (average of 2.0) (Figure 1D). These values are not limiting to the development of forest species. The development of most plants is not affected by $\mathrm{Ca} / \mathrm{Mg}$ ratios between 0.5 and 10 , provided that neither of the two nutrients is deficient (CQFS-RS/SC, 2016). For that reason, it is recommended to use dolomitic lime in degraded soils, because calcitic lime may promote imbalance of $\mathrm{Ca} / \mathrm{Mg}$ ratio (PEDROL et al., 2010).

The increase in $\mathrm{Ca}^{2+}$ and $\mathrm{Mg}^{2+}$ contents increased base saturation (V) in the treatments with lime (V greater than 80\%) in comparison to the control (V of approximately 30\%) in both soil layers (Figure 1E). Palisade grass and the addition of poultry litter did not change $\mathrm{V}$, since the treatments $\mathrm{L}+\mathrm{G}$ and $\mathrm{L}+\mathrm{G}+\mathrm{PL}$ did not differ from one another nor did they differ from the lime treatment. For pine and eucalypt it is recommended to apply lime when $\mathrm{V}$ is less than $40 \%$, and it is not necessary to raise $\mathrm{V}$ above $65 \%$ for an adequate development of these forest species (CQFS-RS/SC, 2016).

Liming also decreased $\mathrm{Al}^{3+}$ saturation (m) to near zero in treatments lime, $\mathrm{L}+\mathrm{G}$ and $\mathrm{L}+\mathrm{G}+\mathrm{PL}$ compared to the control $(\mathrm{m}=66 \%)$ from 0 to $10 \mathrm{~cm}$ (Figure 1F). Values of $\mathrm{m}$ above $20 \%$ are considered high and toxic to most crops (CQFS-RS/SC, 2016). However, forest crops withstand $\mathrm{m}$ higher than $20 \%$, because they are not very sensitive to acidity (GONÇALVES, 1995).

The contents of $\mathrm{P}, \mathrm{K}^{+}$and total organic carbon (TOC) did not differ with the treatments (Table 1). The nutrients $\mathrm{P}$ and $\mathrm{K}^{+}$ were applied with mineral fertilization in all treatments when the experiment was set up in 2001 and reapplied in 2004, apart from the application in the planting pits in $2004 . \mathrm{K}^{+}$ content is considered high in the layer of 0-5 $\mathrm{cm}$ and medium in the layer of $5-10 \mathrm{~cm}$, and $\mathrm{P}$ content is considered high in the layer of 0-5 $\mathrm{cm}$ and low in the layer of $5-10 \mathrm{~cm}$, considering the requirements for forest crops (CQFS-RS/SC, 2016). At first glance, the $\mathrm{P}$ content in the $0-5 \mathrm{~cm}$ layer does not corroborate our theory of lower $\mathrm{P}$ availability due to high $\mathrm{pH}$ in this soil layer and consequent precipitation of Ca-P compounds. However, it is well known that Mehlich-1 extractant may overestimate the available $\mathrm{P}$ in soils with high $\mathrm{pH}$ and calcium phosphate compounds. So, as there was high $\mathrm{pH}$, high $\mathrm{Ca}$, and application of phosphate fertilizers throughout the area, it is expected the high $\mathrm{P}$ availability shown by Mehlich-1 method is not according to the real plant $\mathrm{P}$ availability.

Table 1. Mean \pm standard error of $\mathrm{P}, \mathrm{K}^{+}$, and $\mathrm{Na}^{+}$contents, effective CEC (CEC ${ }_{\text {ef }}$, and total organic carbon (TOC) in two layers (0-5 and $5-10 \mathrm{~cm}$ ) of the constructed soil. Difference between treatments not significant by Tukey test $(\mathrm{p}<0.05)$.

\begin{tabular}{|c|c|c|c|c|c|}
\hline Treament & $\mathbf{P}$ & Ki & $\mathrm{Na}$ & CEC d & $T O C$ \\
\hline \multirow[t]{2}{*}{3} & \multicolumn{3}{|c|}{$\mathrm{mg} \mathrm{kg}^{\prime}$} & $\mathrm{cmol}_{\text {. } \mathrm{kg}^{-1}}$ & $g \mathrm{kF}^{3}$ \\
\hline & \multicolumn{5}{|c|}{ Layer of $0.5 \mathrm{~cm}$} \\
\hline Cootenl & $9.6+3.4$ & $95.3 \neq 0.3$ & $360+3.2$ & $13.9+1.6$ & $14.6+2.8$ \\
\hline time: & $2.2 \pm 1.1$ & $1140=83$ & $46.7 \pm 8.7$ & $17,1 \pm 0.6$ & $12.4 \pm 1.3$ \\
\hline $\mathrm{L}+\mathrm{G}$ & $25.6 \pm 21.1$ & $110,3 \pm 209$ & $45.0 \pm 3.1$ & $19.3=1.1$ & $14.1=4.2$ \\
\hline $\mathrm{L}+\mathrm{G}+\mathrm{PL}$ & $184+3.3$ & $121.7 \neq 26$ & $547 \div 12.5$ & $21,3=29$ & $206=2.0$ \\
\hline \multirow[t]{2}{*}{ CV $(50)$} & 133 & is & 29. & 22 & 34 \\
\hline & \multicolumn{5}{|c|}{ Lyyer of $5-10 \mathrm{~cm}$} \\
\hline Conoul & $0.1 \pm 0.1$ & $81.3 \pm 2.7$ & $36.3 \pm 8.0$ & $11.8=0.9$ & $3.6 \pm 0.4$ \\
\hline Lime & $0 J \pm 0.5$ & $83.3=13$ & $35.7 \pm 4.4$ & $15.7=36$ & $2.3 \pm 1.1$ \\
\hline$L+G$ & $16.2 * 16.2$ & $87,3=80$ & $4.0+11.0$ & $19.1 \div 0.5$ & $7.1+3.1$ \\
\hline$L+G+P L$ & $5.4+12$ & $84.0 \pm 23$ & $507 \neq 10.6$ & $18.8=1.7$ & $6.1 \pm 0.8$ \\
\hline$c V(56)$ & 246 & 8 & 35 & 26 & 68 \\
\hline
\end{tabular}


The averages of $\mathrm{P}$ and $\mathrm{K}^{+}$contents for the layer 0 to $10 \mathrm{~cm}$ are above the critical levels recommended by CQFS-RS/SC (2016) for eucalypt and pine in the south of Brazil, which is $9.0 \mathrm{mg} \mathrm{kg}^{-1}$ of $\mathrm{P}$ and $90 \mathrm{mg} \mathrm{kg}^{-1}$ of $\mathrm{K}^{+}$ for a mean annual increment of wood of $40 \mathrm{~m}^{3}$ $\mathrm{ha}^{-1}$ year $^{-1}$ for eucalypt and of $30 \mathrm{~m}^{3} \mathrm{ha}^{-1}$ year ${ }^{1}$ for pine. The contents of $\mathrm{P}$ and $\mathrm{K}^{+}$are also above the critical levels for mean annual increment of eucalypt wood of $50 \mathrm{~m}^{3} \mathrm{ha}^{-1}$ year${ }^{1}$ in soils of Minas Gerais state, Brazil, which are $5.5 \mathrm{mg} \mathrm{kg}^{-1}$ of $\mathrm{P}$ (mean between critical levels of sandy and clayey soils) and $90 \mathrm{mg}$ $\mathrm{kg}^{-1}$ of $\mathrm{K}^{+}$(BARROS and NOVAIS, 1999).

Even with the increase of $\mathrm{pH}$ and $\mathrm{Ca}^{2+}$ and $\mathrm{Mg}^{2+}$ contents, after the application of lime, the soil effective CEC $\left(\mathrm{CEC}_{\mathrm{ef}}\right)$ did not differ with the treatments (Table 1). The average $\mathrm{CEC}_{\mathrm{ef}}$ was $17 \mathrm{cmol}_{\mathrm{c}} \mathrm{kg}^{-1}$ from 0 to 10 $\mathrm{cm}$ depth (Table 1), considered high for weathered Brazilian soils (CQFS-RS/SC, 2016), as the soil of this study. $\mathrm{Na}^{+}$content was also not affected by the treatments, with a mean value of $44 \mathrm{mg} \mathrm{kg}^{-1}$ from 0 to $10 \mathrm{~cm}$ depth (Table 1). $\mathrm{Na}^{+}$is present in degraded soils generally at small concentrations and, in this case, does not affect the growth of plants.

TOC content in constructed soils is generally very low. The addition of poultry litter and the cultivation of palisade grass were not efficient in increasing the contents of TOC - that is soil organic matter (SOM) - after six years and did not differ among treatments (Table 1). Differences in TOC content of constructed soils have also not been found by Anderson et al. (2008) at depth of 0 to $30 \mathrm{~cm}$ after 11 years of grazing and mulching. In contrast, Bendfeldt et al. (2001) observed a maximum increment of SOM at a depth of 0 to $10 \mathrm{~cm}$ after five years of sewage sludge addition, but the SOM content decreased after 16 years and stabilized due to the growth of vegetation. Anderson et al. (2008) observed a great increase in TOC after 26 years of grazing, equivalent to the TOC content of the undisturbed soil; and Leal et al. (2015) observed a partial recovery of TOC stocks (but less than half of the natural soil stocks) at depth of 0 to $30 \mathrm{~cm}$ after six years of sowing of different grasses. These results indicate the necessity for frequency of application and long term for the increment of TOC in degraded soils (STUMPF et al., 2014) through the introduction of organic materials and the decomposition of aerial part and roots of the plants introduced for the recovery of these areas.

In general, no differences were observed in soil chemical attributes between the treatments lime, $\mathrm{L}+\mathrm{G}$, and $\mathrm{L}+\mathrm{G}+\mathrm{PL}$ (Figure 1), which shows that sowing of palisade grass and organic fertilization with poultry litter did not change soil chemical composition after nine years of first application and six years of reapplication of the treatments. Thus, changes in chemical attributes were mainly due to the application of lime, which does not decrease the importance of using cover crops for revegetation and erosion reduction in degraded areas (HOLL, 2002). In addition, when organic sources such as animal wastes (PARK et al., 2011) and vegetal covering (BENDFELDT et al., 2001) are regularly applied to constructed or degraded soils, there is an improvement in soil physical, chemical and biological quality. These effects were not observed, since only two doses of poultry litter (6 $\mathrm{Mg} \mathrm{ha}^{-1}$ in 2001 and $9 \mathrm{Mg} \mathrm{ha}^{-1}$ in 2004) were applied. Lunardi Neto (2006) also did not observe TOC alteration after six months of treatments reapplication. The climate of the area is $\mathrm{CFa}$ according to Köppen's classification, with high temperatures during the year, a factor that favors the mineralization of the organic matter.

It is important to emphasize that spatial variability is high in soils topographically constructed in degraded areas, with consequent high coefficients of variation for most of the soil chemical and physical attributes. This was also reported by (CAMPOS et al., 2003) in three areas degraded by coal mining. Thus, statistical tests show no differences between treatments (Figure 1 and Table 1). 


\subsection{Soil physical attributes}

The analysis of soil physical attributes almost showed no statistical difference between treatments. Significant difference was only observed for soil penetration resistance (PR) (Figure 2A), which was lower in the treatments $\mathrm{L}+\mathrm{G}$ and $\mathrm{L}+\mathrm{G}+\mathrm{PL}$ (approximately $500 \mathrm{kPa}$ ) compared to the control $(1,300 \mathrm{kPa})$, in the average of layers, but no treatment had PR above $2,000 \mathrm{kPa}$, critical value accepted as restrictive for root growth (STUMPF et al., 2016b). This reduction in PR may be due to higher soil moisture, which has a significant negative correlation with PR in 0-5 cm layer $(r=-0.79)$ and in $5-10 \mathrm{~cm}$ layer $(\mathrm{r}=-0.89)$ (data not shown). The cultivation of palisade grass may have influenced soil moisture in treatments $\mathrm{L}+\mathrm{G}$ and $\mathrm{L}+\mathrm{G}+\mathrm{PL}$. However, as soil volumetric moisture (VM) did not differ between treatments (Figure 2B), the lower PR may be related to the effect of palisade grass root growth on soil decompaction. Several papers have showed that Urochloa brizantha have greater root density and length than other grasses, assisting in the recovery of soil structure by decreasing soil density and resistance to penetration, increasing macroporosity (STUMPF et al., 2014, 2016b, 2018a), and influencing the breakdown of cohesive aggregates (PAULETTO et al., 2016). Reis et al. (2014) also found that Poaceae plants reduced the compaction of constructed soils in Rio Grande do Sul state, Brazil, with reduction of bulk density, and increase of macroporosity, total porosity and TOC.

Open-pit mining activities decrease porosity of constructed soils, especially macropores (WANG et al., 2017). The use of palisade grass as cover crop and organic fertilization were strategies to reduce the existing water erosion, add organic matter, and accelerate the process of soil restructuring. However, no statistical changes in bulk density and total porosity were observed after six years when the treatments control and lime were compared with the treatments $\mathrm{L}+\mathrm{G}$ and $\mathrm{L}+\mathrm{G}+\mathrm{PL}$ (Table 2), corroborating what was observed after six months by Lunardi Neto et al. (2008).

Total porosity (TP) and microporosity (Micro) had averages of 0.53 and $0.44 \mathrm{~m}^{3} \mathrm{~m}^{-3}$, respectively, in the 0 to $10 \mathrm{~cm}$ soil layer (Table 2). In the same layer, bulk density (BD) had an average of $1.34 \mathrm{Mg} \mathrm{m}^{-3}$ (Table 2), with no change in comparison to the mean of $\mathrm{BD}$ observed after six months (LUNARDI NETO et al., 2008). Although it is a constructed soil, this BD is below the estimated critical BD for soils of loam texture $\left(1.60 \mathrm{Mg} \mathrm{m}^{-3}\right.$, according to Reichert et al. (2003)). However, the average macroporosity (Macro) in the soil layer of 0 to $10 \mathrm{~cm}$ was $0.09 \mathrm{~m}^{3} \mathrm{~m}^{-3}$ (Table 2), less than the minimum limit of aeration porosity required for adequate crops growth, considered as $0.10 \mathrm{~m}^{3} \mathrm{~m}^{-3}$ (REICHERT et al., 2003). Below this aeration porosity the gas diffusion coefficient is practically zero (XU et al., 1992). Therefore, this soil has restricted aeration, mainly in periods of greater rainfall and soil moisture.

Table 2. Mean \pm standard error of soil bulk density (BD), total porosity (TP), macroporosity (Macro) and microporosity (Micro) in two layers $(0-5$ and $5-10 \mathrm{~cm})$ of the constructed soil. Difference between treatments not significant by Tukey test ( $\mathrm{p}$ $<0.05)$.

\begin{tabular}{|c|c|c|c|c|}
\hline \multirow{2}{*}{ Treaimets } & $\mathrm{BD}$ & TP & Macre & Micas \\
\hline & $\mathrm{Mg} \|^{-1}$ & \multicolumn{3}{|c|}{ 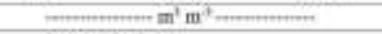 } \\
\hline & \multicolumn{4}{|c|}{ Layer of $0.5 \mathrm{~cm}$} \\
\hline Contral & $1.34=0.05$ & $0,55=0.01$ & $0.14=0.02$ & $0.41=0.02$ \\
\hline Lime & $1.35 \times 0.04$ & $0.53 \neq 0.02$ & $0.09 \pm 0.02$ & $0.45 * 0.00$ \\
\hline$L+G$ & $123 \approx 0.03$ & 0.57 .001 & $0.12 * 003$ & $0.45 * 0.03$ \\
\hline$L+G+F L$ & $1.21 \div 0.08$ & $0.57=0.03$ & $0.08 \div 0.01$ & $0.49 \pm 0.02$ \\
\hline \multirow[t]{2}{*}{$\mathrm{CV}\langle \%)$} & 8 & 6 & 37 & 10 \\
\hline & \multicolumn{4}{|c|}{ Layer of $5-10 \mathrm{~cm}$} \\
\hline Contral & $1+1=0.07$ & $0.50=0.02$ & $0.10=0.02$ & $0.40 \pm 0.01$ \\
\hline Lime & $1.45=0.06$ & $0.51=0.02$ & $0.07 \pm 0.01$ & $0.44 \pm 0.01$ \\
\hline $\mathrm{L}+\mathrm{G}$ & $1.35 \div 0.03$ & $0.52=0.01$ & $0.08=0.01$ & $0,44 \pm 0.02$ \\
\hline L+G+PL & $1.36 * 0.02$ & $0.52 \approx 0.01$ & $0.06 \approx 0.00$ & $0.46 * 0.01$ \\
\hline $\mathrm{CV}(\boldsymbol{N})$ & 6 & 5 & 31 & 6 \\
\hline
\end{tabular}



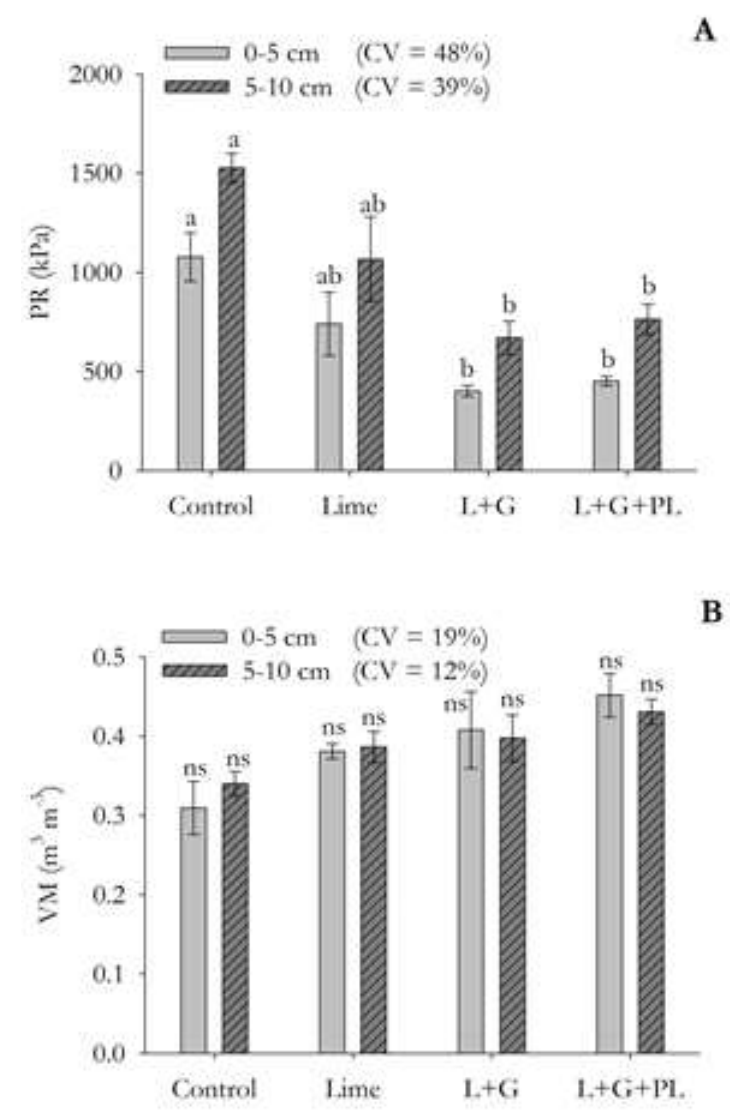

Figure 2. Soil penetration resistance (PR) (A) and soil volumetric moisture (VM) at the time of PR determination (B) in two layers (0-5 and $5-10 \mathrm{~cm})$ of the constructed soil. For each layer, bars with different letters differ from each other and bars with ns (not significant) do not differ by Tukey test $(\mathrm{p}<0.05)$ and error bars denote standard error.

Legend: $\mathrm{L}+\mathrm{G}$ - lime + palisade grass; $\mathrm{L}+\mathrm{G}+\mathrm{PL}-$ lime + palisade grass + poultry litter; $\mathrm{CV}-$ coefficient of variation.

The evaluation of this study six months after reapplication of treatments, the macropores volume was lower $\left(0.05 \mathrm{~m}^{3} \mathrm{~m}^{-3}\right)$ (LUNARDI NETO et al., 2008) than after six years - our data $\left(0.09 \mathrm{~m}^{3} \mathrm{~m}^{-3}\right)$, considering the soil layer of 0 to $10 \mathrm{~cm}$. This indicates that the soil is gradually restructured regardless of the treatments, although it still has low Macro and, consequently, low diffusion of gases. Macropores are the main responsible for the rapid diffusion of gases in the soil and can increase with time in constructed soils, due to plants growth (GUEBERT and GARDNER, 2001; WANG et al., 2017).

\subsection{Growth of pine and eucalypt}

After six years of the forest species planting, the application of lime had negative effects on pine and eucalypt growth. Pine had higher growth in the control treatment, with a diameter at breast height (DBH) of $12.1 \mathrm{~cm}$ (Figure 3A) and height of $10.0 \mathrm{~m}$ (Figure 3B), similar values to those found in commercial pine plantations of similar age (LEITE et al., 2006), and lower growth in the other treatments. This result is attributed to the lime doses applied in the treatments lime, $\mathrm{L}+\mathrm{G}$ and $\mathrm{L}+\mathrm{G}+\mathrm{PL}$, which reached $\mathrm{pH}$ around 7.0 in the mean of 0 to $10 \mathrm{~cm}$ soil depth between the planting rows. Due to the difficulty of lime incorporating in the soil, the $\mathrm{pH}$ was above 7.0 in the $0-5 \mathrm{~cm}$ layer.
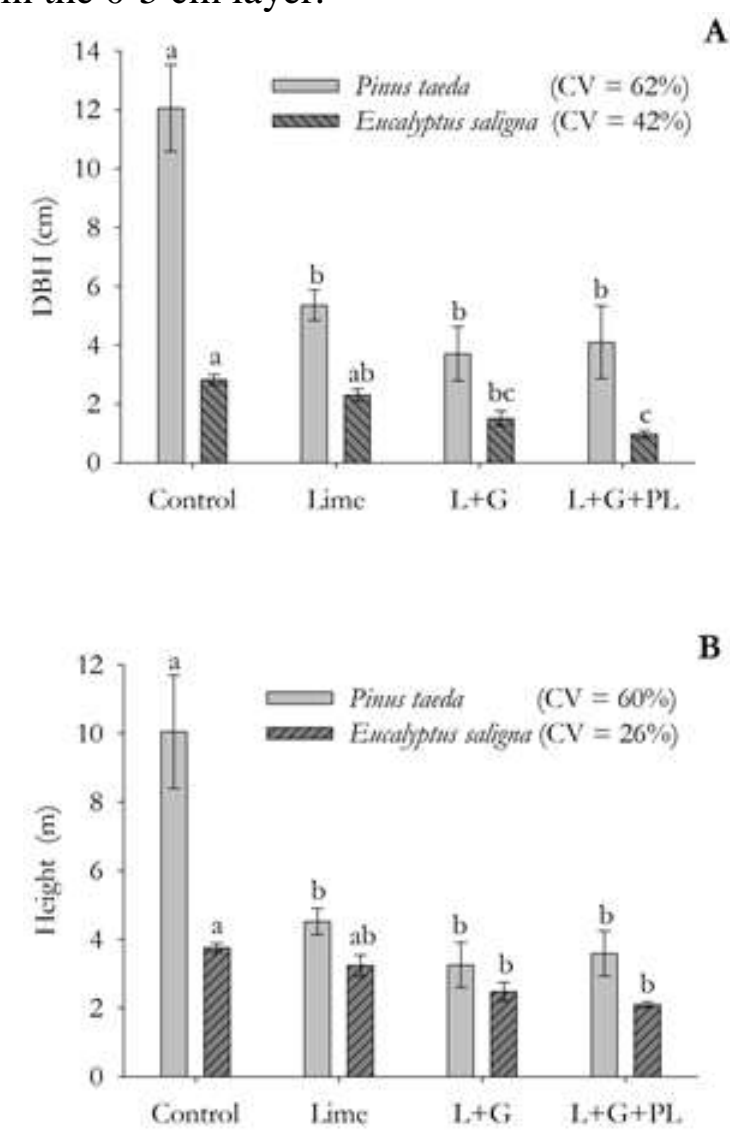

Figure 3. Diameter at breast height (DBH) (A) and height (B) of Pinus taeda and Eucalyptus saligna in constructed soil. For 
each forest species, bars with different letters differ from each other and bars with ns (not significant) do not differ by Tukey test ( $p$ $<0.05)$ and error bars denote standard error.

Legend: $\mathrm{L}+\mathrm{G}$ - lime + palisade grass; $\mathrm{L}+\mathrm{G}+\mathrm{PL}-$ lime + palisade grass + poultry litter; $\mathrm{CV}$ - coefficient of variation.

Eucalypt also had greater growth in the control treatment, decreasing with the application of lime along with the use of palisade grass and poultry litter (treatments $\mathrm{L}+\mathrm{G}$ and $\mathrm{L}+\mathrm{G}+\mathrm{PL}$ ), but had very low growth throughout the area (Figure 3). Eucalyptus saligna populations at six years of age are found in southern Brazil with DBH around $15.0 \mathrm{~cm}$ and height of $25.0 \mathrm{~m}$ (BERGER et al., 2002). The lower eucalypt growth in $\mathrm{L}+\mathrm{G}$ and $\mathrm{L}+\mathrm{G}+\mathrm{PL}$ may be due to the competition for water and nutrients with palisade grass. In the $\mathrm{L}+\mathrm{G}+\mathrm{PL}$ treatment may still have occurred competition for nitrogen $(\mathrm{N})$ because the addition of wood shavings from the poultry litter (addition of carbon, C) stimulates the microbial biomass, requiring $\mathrm{N}$ for its decomposition due to the high $\mathrm{C} / \mathrm{N}$ ratio. The mineralization process is intense during the first months after application of the poultry litter, which indicates that competition at the beginning of the forest species development (also including competition with palisade grass) affected the eucalypt growth in subsequent years.

However, the low growth of eucalypt in all treatments may be due chemical restrictions promoted by treatments with lime (as $\mathrm{P}$ deficiency, which also occurs in the control due to high acidity), but also due to the soil physical restrictions as compaction and low aeration in depths also below $10 \mathrm{~cm}$, commonly observed in constructed soils (STUMPF et al., 2016b). Non-restrictive soil physical conditions are also important in the more superficial layer because most of the eucalypt fine roots are found in the first $20 \mathrm{~cm}$ of soil depth (WITSCHORECK et al., 2003).

A negative correlation was observed between DBH and height of pine and eucalypt with $\mathrm{pH}$ in water, $\mathrm{Ca}^{2+}, \mathrm{Mg}^{2+}, \mathrm{CEC}_{\mathrm{ef}}, \mathrm{V}$ and Micro (Table 3). Positive correlation for pine growth was observed with $\mathrm{Ca} / \mathrm{Mg}$ ratio, $\mathrm{m}$, Macro and PR; and for eucalypt with Macro, $\mathrm{BD}$ and PR (Table 3). Significant negative correlations between $\mathrm{Ca}^{2+}, \mathrm{Mg}^{2+}, \mathrm{CEC}_{\mathrm{ef}}$ and $\mathrm{V}$ with the growth of forest species did not mean that the trees grew less due to the increase in soil fertility, but that the excessive elevation of $\mathrm{pH}$ increased $\mathrm{Ca}^{2+}$ and $\mathrm{Mg}^{2+}$ contents, $\mathrm{CEC}_{\mathrm{ef}}$ and $\mathrm{V}$, while at the same time it hampered the growth of pine and eucalypt by imbalance of soil nutrients. The same occurs in relation to the positive correlations of $\mathrm{DBH}$ and height of pine with $\mathrm{Ca} / \mathrm{Mg}$ ratio, $\mathrm{m}$ and $\mathrm{PR}$, because these attributes were significantly higher in the control treatment, in which pine growth was higher. While negative correlations with Micro and positive with Macro indicate the influence of soil physical quality on the growth of these forest species, especially eucalypt.

Table 3. Pearson's linear correlation coefficients between the attributes of the constructed soil and the growth variables of Pinus taeda and Eucalyptus saligna - diameter at breast height (DBH) and height.

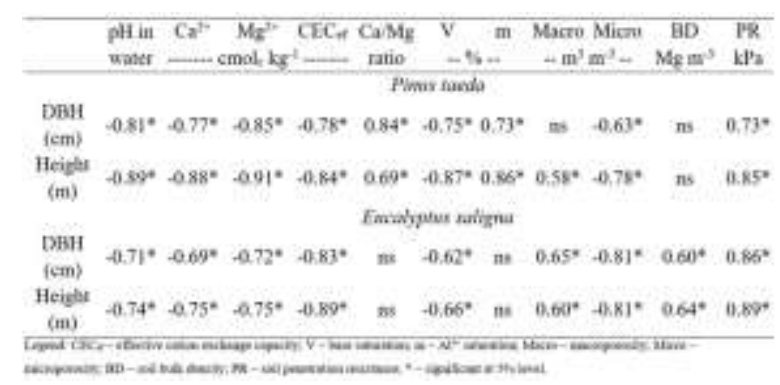

Thus, the decrease of pine growth in the treatments with lime is mainly related to the excessive elevation of $\mathrm{pH}$ by the application and reapplication of lime at doses recommended based on the SMP $\mathrm{pH}$, but also to the soil physical condition, as observed by Bognola et al. (2010). On the other hand, the growth of eucalypt, although also affected by the soil chemical conditions, may have been influenced by the low Macro of the 
constructed soil, which did not differ between treatments (Table 2). Deficiencies in soil aeration restrict root respiration and nutrient uptake by plants (BELLOTE and DEDECEK, 2006), with eucalypt being more affected than pine.

Although pine has low nutritional requirement (FERREIRA et al., 2004), excessive $\mathrm{pH}$ increase may have affected its growth due to the unavailability of nutrients (P, Fe, Zn, Cu, Mn). Lopes et al. (2013) concluded that $\mathrm{P}$ was the main variable that affected the growth of fine roots of Pinus taeda with 15 years of age, and especially in the soil layer of 0 to $10 \mathrm{~cm}$. Therefore, the highest DBH and height of pine in the control may be related to the addition of lime at the equivalent dose of $18 \mathrm{Mg} \mathrm{ha}^{-1}$ only in the planting pit, which promoted soil correction to a more adequate $\mathrm{pH}$ for the trees, which is close to 5.5 (CQFS-RS/SC, 2016), benefiting the establishment of seedlings and their initial growth. In the $\mathrm{pH}$ range between 5.5 and 6.5, there is also greater availability of P (MELLO and PEREZ, 2009), which is important for pine due to its volume increase in response to phosphate fertilization (VOGEL et al., 2005). Therefore, for adequate pine growth until the age of six years, it was adequate to correct the acidity with lime only in the planting pit in constructed soils after coal mining, even with accelerated acidification of the soil due to the presence of pyrite. This acidification in our study can be proven by the occurrence of $\mathrm{Al}^{3+}$, even though in very low contents $(<0.04$ $\mathrm{cmol}_{\mathrm{c}} \mathrm{kg}^{-1}$, data not shown) in the treatments that received lime and whose $\mathrm{pH}$ is greater than 5.5 (Figure 1).

Eucalypt also has tolerance to acid soil conditions but is more demanding in terms of fertility compared to pine (PAIVA et al., 2011), especially in the initial stages of growth (GONÇALVES et al., 2015). Due to this, eucalypt growth was also hampered by the chemical problems in treatments with lime and mainly by the competition for nutrients with palisade grass and microbial biomass. Eucalypt has a high requirement of $\mathrm{P}$ in the year of establishment (NOVAIS et al., 1982), and as there was excessive elevation of $\mathrm{pH}$ by liming (Figure 1A), precipitation of calcium phosphates must have caused $\mathrm{P}$ deficiency (HAYNES, 2009), as well as micronutrients deficiency due to increased adsorption to soil negative charges.

However, due to low eucalypt growth in all treatments (Figure 3), this may have been affected by soil physical restrictions. The soil has a macroporosity lower than $0.10 \mathrm{~cm}^{3}$ $\mathrm{cm}^{-3}$ (Table 2), which greatly reduces its aeration capacity (XU et al., 1992) and impairs root development and water and nutrients absorption. However, further studies are needed to understand the low growth of eucalypt in constructed soil after coal mining.

For both forest species, the application of lime is indicated at small doses (1.5 to 2.0 $\mathrm{Mg} \mathrm{ha}^{-1}$ ) to supplement the soil with $\mathrm{Ca}^{2+}$ and $\mathrm{Mg}^{2+}$, having little importance to neutralize the toxicity of $\mathrm{Al}^{3+}$ and $\mathrm{Mn}^{2+}$ (PAIVA et al., 2011; GONÇALVES et al., 2015). Therefore, the rehabilitation of degraded soils by acidity correction based on SMP $\mathrm{pH}$ to raise soil $\mathrm{pH}$ to 6.0 is not feasible when the objective is the commercial planting of forest species.

In addition, it is important to consider that Urochloa brizantha has high dispersal capacity and are not recommended for the restoration of degraded areas due to the risks of biological contamination (ESPÍNDOLA et al., 2005), but this grass species has greater recovery potential to the other grasses for rehabilitation of soil physical and soil organic matter of constructed soils after coal mining (STUMPF et al., 2014, 2016a,b, 2018a; LEAL et al., 2015; PAULETTO et al., 2016).

\section{Conclusions}

The difficulty of lime incorporation in the constructed soil after degradation by coal mining raised $\mathrm{pH}$ excessively in the soil surface layer, mainly until $5 \mathrm{~cm}$ depth even under conditions of high acidification and caused imbalance of nutrients in the soil. 
Poultry litter and palisade grass used as soil rehabilitation methods along with lime did not modify the chemical and most physical attributes of the constructed soil after six years, but palisade grass reduced soil penetration resistance.

The application of lime, at doses recommended based on SMP $\mathrm{pH}$, reduced the growth of pine after six years due to nutritional imbalances. However, reforestation with Pinus taeda in constructed soils was feasible with application of lime only in the planting pit (lower total lime dose).

The growth of eucalypt decreased with organic fertilization with poultry litter and covering with Urochloa brizantha due to competitions for nutrients but was considerably lower across the area of the constructed soil after coal mining in comparison to the growth observed in commercial areas. Thus, Eucalyptus saligna seems not to be indicated for reforestation in similar areas probably due to soil physical deficiencies such as low aeration.

\section{ACKNOWLEDGMENTS}

To the Santa Catarina State University (UDESC); CNPq (by research productivity grant to the second and third authors); and CAPES (by master's scholarship to the first author).

\section{REFERENCES}

ANDERSON, J. D.; INGRAM, L. J.; STAHL, P. D. Influence of reclamation management practices on microbial biomass carbon and soil organic carbon accumulation in semiarid mined lands of Wyoming. Applied Soil Ecology, v. 40, n. 2, p. 387-397, 2008.

BARROS, N. F.; NOVAIS, R. F. Eucalipto. In: RIBEIRO, A. C.; GUIMARÃES, P. T. G.; ALVAREZ V., V. H. (Eds.). Recomendações para o uso de corretivos e fertilizantes em
Minas Gerais: 5 ${ }^{\mathbf{a}}$ Aproximação. Viçosa: Comissão de Fertilidade do Solo do Estado de Minas Gerais, 1999. p. 303-305.

BELLOTE, A. F. J.; DEDECEK, R. A. Atributos físicos e químicos do solo e suas relações com o crescimento e a produtividade do Pinus taeda. Pesquisa Florestal Brasileira, v. 53, p. 21-38, 2006.

BENDFELDT, E. S.; BURGER, J. A.; DANIELS, W. L. Quality of amended mine soils after sixteen years. Soil Science Society of America Journal, v. 65, n. 6, p. 17361744, 2001.

BERGER, R.; SCHNEIDER, P. R.; FINGER, C. A. G.; HASELEIN, C. R. Efeito do espaçamento e da adubação no crescimento de um clone de Eucalyptus saligna Smith. Ciência Florestal, v. 12, n. 2, p. 75-87, 2002.

BITENCOURT, D. G. B.; PINTO, L. F. S.; PAULETTO, E. A.; SILVA, M. T.; GARCIA, G. F. Geração de drenagem ácida e de contaminação por metais pesados em perfis de solos construídos em área de mineração de carvão. Revista Brasileira de Ciência do Solo, v. 39, n. 6, p. 1821-1834, 2015.

BLAKE, G. R.; HARTGE, K. H. Bulk Density. In: KLUTE, A. (Ed.). Methods of soil analysis. Part 1-Physical and mineralogical methods. Madison: Soil Science Society of America, American Society of Agronomy, 1986. p. 363-375.

BOGNOLA, I. A.; DEDECEK, R. A.; LAVORANTI, O. J.; HIGA, A. R. Influência de propriedades físico-hídricas do solo no crescimento de Pinus taeda. Pesquisa 
Florestal Brasileira, v. 30, n. 61, p. 37-49, 2010.

CAMPOS, M. L.; ALMEIDA, J. A. DE; SILVEIRA, C. B. DA; GATIBONI, L. C.; ALBUQUERQUE1, J. A.; MAFRA1, Á. L.; MIQUELLUTI, D. J.; FILHO, O. K.; SANTOS, J. C. P. Impactos no solo provocados pela mineração e depósito de rejeitos de carvão mineral. Revista de Ciências Agroveterinárias, v. 9, n. 2, p. 198205, 2010.

CAMPOS, M. L.; ALMEIDA, J. A.; SOUZA, L. S. Avaliação de três áreas de solo construído após mineração de carvão a céu aberto em Lauro Müller, Santa Catarina. Revista Brasileira de Ciência do Solo, v. 27, n. 6, p. 1123-1137, 2003.

CFS-RS/SC - COMISSÃO DE FERTILIDADE DO SOLO DOS ESTADOS DO RIO GRANDE DO SUL E SANTA CATARINA. Recomendações de adubação e calagem para os estados do Rio Grande do Sul e Santa Catarina. 3. ed. Passo Fundo: Sociedade Brasileira de Ciência do Solo, Núcleo Regional Sul, 1994.

CLAESSEN, M. E. C.; BARRETO, W. D. O.; PAULA, J. L. DE; DUARTE, M. N. Manual de Métodos de Análise de Solo. 2. ed. Rio de Janeiro: Empresa Brasileira de Pesquisa Agropecuária, Centro Nacional de Pesquisa de Solos, 1997.

COSTA, S.; ZOCCHE, J. J. Fertilidade de solos construídos em áreas de mineração de carvão na região sul de Santa Catarina. Revista Árvore, v. 33, n. 4, p. 665-674, 2009.
CQFS-RS/SC - COMISSÃO DE QUÍMICA E FERTILIDADE DO SOLO DOS ESTADOS DO RIO GRANDE DO SUL E SANTA CATARINA. Manual de adubação e de calagem para os estados do Rio Grande so Sul e Santa Catarina. 10. ed. Porto Alegre: Sociedade Brasileira de Ciência do Solo, Núcleo Regional Sul, 2004. v. 10 ed.

EPE - EMPRESA DE PESQUISA ENERGÉTICA (BRASIL). Brazilian Energy Balance 2017 Year 2016. Rio de Janeiro: [s.n.].

EQUIPE ESTATCAMP. Software Action Stat. Disponível em: <http://www.portalaction.com.br>.

ESPÍNDOLA, M. B. DE; BECHARA, F. C.; BAZZO, M. S.; REIS, A. Recuperação ambiental e contaminação biológica: aspectos ecológicos e legais. Biotemas, v. 18, n. 1, p. 27-38, 2005.

FERREIRA, C. A.; SILVA, H. D.; BELLOTE, A. F. J. Pesquisa sobre nutrição de pinus no Sul do Brasil. Revista da Madeira, v. 83, p. 36-43, 2004.

GAIVIZZO, L. H. .; VIDOR, V.; TEDESCO, M. J.; BISSANI, C. A. Potencial poluidor de rejeitos carboníveros. II - Efeito da recuperação com camadas de solo sobre as plantas e a população microbiana. Ciência Rural, v. 32, n. 6, p. 955-961, 2002.

GONÇALVES, J. L. D. M. Recomendações de adubação para Eucalyptus, Pinus e espécies típicas da mata atlântica. Documentos Florestais, n. 15, p. 1-23, 1995. 
GONÇALVES, J. L. DE M.; ALVARES, C. A.; SOUZA, A. H. B. N.; JUNIOR, J. C. A. Caracterização edafoclimática e manejo de solos das áreas com plantações de eucalipto. In: SCHUMACHER, M. V.; VIERA, M. (Eds.). Silvicultura do Eucalipto no Brasil. Santa Maria: Universidade Federal de Santa Maria, 2015. p. 113-156.

GONZÁLEZ-ALDAY, J.; MARRS, R. H.; MARTÍNEZ-RUIZ, C. Soil seed bank formation during early revegetation after hydroseeding in reclaimed coal wastes. Ecological Engineering, v. 35, n. 7, p. 10621069, 2009.

GUEBERT, M. D.; GARDNER, T. W. Macropore flow on a reclaimed surface mine: infiltration and hillslope hydrology. Geomorphology, v. 39, n. 3-4, p. 151-169, 2001.

HAYNES, R. J. Reclamation and revegetation of fly ash disposal sites - Challenges and research needs. Journal of Environmental Management, v. 90, n. 1, p. 43-53, 2009.

HOLL, K. D. Long-term vegetation recovery on reclaimed coal surface mines in the eastern USA. Journal of Applied Ecology, v. 39, n. 6, p. 960-970, 2002.

LEAL, O. DOS A.; CASTILHOS, R. M. V.; PAULETTO, E. A.; PINTO, L. F. S.; PILLON, C. N.; PENNING, L. H.; SANTOS, D. C. DOS. Organic Matter Fractions and Quality of the Surface Layer of a Constructed and Vegetated Soil After Coal Mining. II Physical Compartments and Carbon
Management Index. Revista Brasileira de Ciência do Solo, v. 39, n. 3, p. 895-902, 2015.

LEITE, H. G.; NOGUEIRA, G. S.; MOREIRA, A. M. Efeito do espaçamento e da idade sobre variáveis de povoamentos de Pinus Taeda L. Revista Árvore, v. 30, n. 4, p. 603-612, 2006.

LOPES, V. G.; SCHUMACHER, M. V.; MÜLLER, I.; CALIL, F. N.; WITSCHORECK, R.; LIBERALESSO, E. Variáveis físicas e químicas do solo importantes na distribuição de raízes finas em um povoamento de PinusTaeda L. no Nordeste do Rio Grande do Sul. Revista Ecologia e Nutrição Florestal - ENFLO, v. 1, n. 1, p. 14-23, 2013.

LUNARDI NETO, A. Métodos para reabilitação de solo reconstruído após mineração de carvão. [s.l.] Universidade do Estado de Santa Catarina, 2006.

LUNARDI NETO, A.; ALBUQUERQUE, J. A.; ALMEIDA, J. A. DE; MAFRA, Á. L.; MEDEIROS, J. C.; ALBERTON, A. Atributos físicos do solo em área de mineração de carvão influenciados pela correção da acidez, adubação orgânica e revegetação. Revista Brasileira de Ciência do Solo, v. 32, n. 4, p. 1379-1388, 2008.

MELLO, J. W. V.; PEREZ, D. V. Equilíbrio químico das reações no solo. In: MELO, V. F.; ALLEONI, L. R. (Eds.). Química e Mineralogia do Solo: Parte I-Conceitos básicos. Viçosa: Sociedade Brasileira de Ciência do Solo, 2009. p. 152-250. 
NOVAIS, R. F.; BARROS, N. F.; NEVES, J. C. L.; COUTO, C. Níveis críticos de fósforo no solo para o eucalipto. Revista Árvore, v. 6, p. 29-37, 1982.

NOVAIS, R. F.; SMYTH, T. J.; NUNES, F. N. Fósforo. In: ROBERTO FERREIRA DE NOVAIS; ALVAREZ V., V. H.; BARRO, N. F. DE; FONTES, R. L.; CANTARUTTI, R. B.; NEVES, J. C. L. (Eds.). Fertilidade do solo. Viçosa: Sociedade Brasileira de Ciência do Solo, 2007. p. 471-550.

PAIVA, H. N. DE; JACOVINE, L. A. G.; RIBEIRO, G. T.; TRINDADE, C. Cultivo de eucalipto: implantação e manejo. Viçosa: Aprenda Fácil, 2011.

PARK, J. H.; EDRAKI, M.; MULLIGAN, D.; JANG, H. S. The application of coal combustion by-products in mine site rehabilitation. Journal of Cleaner Production, v. 84, p. 761-772, 2014.

PARK, J. H.; LAMB, D.; PANEERSELVAM, P.; CHOPPALA, G.; BOLAN, N.; CHUNG, J.-W. Role of organic amendments on enhanced bioremediation of heavy metal(loid) contaminated soils. Journal of Hazardous Materials, v. 185, n. 2-3, p. 549-574, 2011.

PAULETTO, E. A.; STUMPF, L.; PINTO, L. F. S.; SILVA, T. S. DA; AMBUS, J. V.; GARCIA, G. F.; JUNIOR, L. A. D.; SCHEUNEMANN, T.; ALBERT, R. P. Reclamation of a degraded coal-mining area with perennial cover crops. Revista Brasileira de Ciência do Solo, v. 40, n. 40:e0150482, p. 1-13, 2016.
PEDROL, N.; PUIG, C. G.; SOUZA, P.; FORJÁN, R.; VEGA, F. A.; ASENSIO, V.; GONZÁLEZ, L.; CERQUEIRA, B.; COVELO, E. F.; ANDRADE, L. Soil fertility and spontaneous revegetation in lignite spoil banks under different amendments. Soil and Tillage Research, v. 110, n. 1, p. 134-142, 2010.

QUADROS, P. D. DE; ZHALNINA, K.; DAVIS-RICHARDSON, A. G.; DREW, J. C.; MENEZES, F. B.; CAMARGO, F. A. D. O.; TRIPLETT, E. W. Coal mining practices reduce the microbial biomass, richness and diversity of soil. Applied Soil Ecology, v. 98, p. 195-203, 2016.

REICHERT, J. M.; REINERT, D. J.; BRAIDA, J. A. Qualidade dos solos e sustentabilidade de sistemas agrícolas. Ciência \& Ambiente, v. 27, p. 29-48, 2003.

REINERT, D. J.; REICHERT, J. M. Coluna de areia para medir a retenção de água no solo - Protótipos e teste. Ciencia Rural, v. 36, n. 6, p. 1931-1935, 2006.

REIS, D. A.; LIMA, C. L. R. DE; PAULETTO, E. A. Resistência tênsil de agregados e compressibilidade de um solo construído com plantas de cobertura em área de mineração de carvão em Candiota, RS. Revista Brasileira de Ciência do Solo, v. 38, n. 2, p. 669-678, 2014.

SANTA CATARINA. Lei $\mathbf{n}^{\mathbf{0}} \mathbf{1 4 . 6 7 5}$, de 13 de abril de 2009. Institui o Código Estadual do Meio Ambiente e estabelece outras providências. Diário Oficial do Estado de Santa Catarina, Florianópolis, SC, 2009, 2009. 
SANTA CATARINA. Resolução CONSEMA $n^{0}$ 08, de 14 de setembro de 2012. Reconhece a Lista Oficial de Espécies Exóticas Invasoras no Estado de Santa Catarina e dá outras providências. Diário Oficial do Estado de Santa Catarina $\mathbf{n}^{\circ}$ 19429, Florianópolis, SC, 2 out. 2012. p. 36, 2012.

SANTOS, H. G. DOS; JACOMINE, P. K. T.; ANJOS, L. H. C. DOS; OLIVEIRA, V. Á. DE; LUMBRERAS, J. F.; COELHO, M. R.; ALMEIDA, J. A. DE; FILHO, J. C. DE A.; OLIVEIRA, J. B. DE; CUNHA, T. J. F. Brazilian Soil Classification System. Brasília: Embrapa, 2018.

SAS INSTITUTE. Free Statistical Software, SAS University Edition | SASSAS Documentation, 2017.

STUMPF, L.; DOS ANJOS LEAL, O.; PAULETTO, E. A.; PINTO, L. F. S.; REIS, D. A.; PINTO, M. A. B.; TUCHTENHAGEN, I. K. Tensile strength and organic matter fractions in aggregates of a grass-covered mined soil under early stage recovery. Soil and Tillage Research, v. 176, p. 69-76, 2018a.

STUMPF, L.; PAULETTO, E. A.; FERNANDES, F. F.; SUZUKI, L. E. A. S.; SILVA, T. S. DA; PINTO, L. F. S.; LIMA, C. L. R. DE. Perennial grasses for recovery of the aggregation capacity of a reconstructed soil in a coal mining area in southern Brazil. Revista Brasileira de Ciência do Solo, v. 38, n. 1, p. 327-335, 2014.
STUMPF, L.; PAULETTO, E. A.; PINTO, L. F. S. Soil aggregation and root growth of perennial grasses in a constructed clay minesoil. Soil and Tillage Research, v. 161, p. 71-78, 2016a.

STUMPF, L.; PAULETTO, E. A.; PINTO, L. F. S.; GARCIA, G. F.; AMBUS, J. V.; SILVA, T. S. DA; PINTO, M. A. B.; TUCHTENHAGEN, I. K. Condição física e desenvolvimento radicular de gramíneas em solo construído após mineração de carvão. Pesquisa Agropecuária Brasileira, v. 51, n. 9, p. 1078-1087, 2016b.

STUMPF, L.; PAULETTO, E. A.; PINTO, L. F. S.; GEISSLER, L. O.; CASTILHOS, D. D.; DE LIMA DE SOUZA, D.; PIMENTEL, J. P.; DUTRA, L. A. Biological and physical quality of a mined soil under revegetation with perennial grasses. Revista Brasileirade Ciencias Agrarias, v. 13, n. 1, p. 1-7, 2018b.

TEDESCO, M.; GIANELLO, C.; BISSANI, C.; BOHNEN, H.; VOLKWEISS, S. Análises de solo, plantas e outros materiais. Porto Alegre: Universidade Federal do Rio Grande do Sul, 1995.

VOGEL, H. L. M.; SCHUMACHER, M. V.; STORCK, L.; WITSCHORECK, R. Crescimento inicial de Pinus taeda L. relacionado a doses de $\mathrm{N}, \mathrm{P}$ e $\mathrm{K}$. Ciência Florestal, v. 15, n. 2, p. 199-206, 2005.

WANG, J.; GUO, L.; BAI, Z. Variations in pore distribution of reconstructed soils induced by opencast mining and land rehabilitation based on computed tomography images. Archives of Agronomy and Soil Science, v. 63, n. 12, p. 1685-1696, 2017. 
WANG, Z.; SILVA, L. C. R.; SUN, G.; LUO, P.; MOU, C.; HORWATH, W. R. Quantifying the impact of drought on soil-plant interactions: a seasonal analysis of biotic and abiotic controls of carbon and nutrient dynamics in high-altitudinal grasslands. Plant and Soil, v. 389, n. 1-2, p. 59-71, 2015.

WITSCHORECK, R.; VALDIRSCHUMACHER, M.; WINCKLERCALDEIRA, M. Estimativa da biomassa e do comprimento de raízes finas em Eucalyptus urophylla S.T. Blake no município de Santa Maria-RS. Revista Árvore, v. 27, n. 2, p. 177-183, 2003.

XU, X.; NIEBER, J. L.; GUPTA, S. C. Compaction effect on the gas diffusion coefficient in soils. Soil Science Society of America Journal, v. 56, n. 6, p. 1743, 1992.

USDA - United States Department of Agriculture. Keys to Soil Taxonomy. 11. ed. Washington: USDA-NRCS, 2010.

Submetido: 25/07/2019.

Aceito: 08/04/2020. 